\title{
TRADISI MAJEJAHITAN: SEBUAH TINJAUAN IDENTITAS WANITA HINDU BALI DALAM ANALISIS TEORI CULTURE LAG
}

\author{
Oleh Putu Sabda Jayendra \\ Karyasiswa S3 Pascasarjana IHDN Denpasar
}

\begin{abstract}
Tradition Majejahitan a hereditary habits that have been embedded as a distinctive identity for the women of Hindu Bali. In the dynamics of socio-cultural changes, globalization brought rapid advances in science and technology as well as the consequences increasing demands of complex life. The implication for this tradition is waning social interaction between Hindu Balinese women, meaning the loss of noble values contained therein, changes in the value of Majejahitan Tradition and of the sacred into the profane, and ultimately lead to an identity crisis among women Hindu Bali.
\end{abstract}

Keywords: Majejahitan Tradition, Identity, Hindu Balinese Women, Globalization

\section{PENDAHULUAN}

Pelaksanaan ajaran agama Hindu di Bali sangat kental dengan nuansa budaya dan tradisi lokal, sehingga orang awam sukar membedakan antara praktik keagamaan dengan budaya dan tradisi setempat. Kehidupan budaya beragama Hindu dan budaya Bali tampak bersinergi dan merupakan satu kesatuan yang tidak terpisahkan. Agama Hindu menempati posisi sebagai jiwa dan sumber nilai budaya Bali. Kedatangan agama Hindu di Bali disambut dengan adaptasi budaya yang memunculkan kearifan lokal atau yang populer dikenal dengan local genius (Titib, 2007:41). Titib (2007:41) menyatakan bahwa kearifan lokal memberi rona dan mewarnai kehidupan agama Hindu dan budaya Bali. Agama Hindu memberikan pencerahan kepada masyarakat Bali dengan tetap melestarikan kepercayaan dan tradisi yang telah ada sebelumnya. Salah satu aktivitas tradisi yang umum terkait dengan kehidupan beragama di Bali adalah Tradisi Majejahitan.
Tradisi Majejahitan merupakan suatu kegiatan merangkai bahan-bahan upakara yang biasanya dilaksanakan oleh para wanita Hindu Bali, baik menjelang hari-hari besar keagamaan Hindu maupun kegiatan-kegiatan yang berhubungan dengan penyelenggaraan yadnya lainnya. Tradisi Majejahitan merupakan suatu kebiasaan yang telah dilaksanakan turuntemurun dan menjadi sebuah identitas umum bagi para wanita Hindu di Bali. Bahkan di kalangan masyarakat Bali terdapat sebuah pepatah yang menyatakan "bukan wanita Bali namanya jika tidak bisa majejahitan". Fenomena yang terjadi secara umum di Bali adalah bahwa keberlangsungan tradisi ini terindikasi semakin meluntur. Kemajuan zaman di era globalisasi turut berimplikasi pada dinamika perubahan sosial masyarakat Bali.

Pada hakikatnya, perubahan sosial tidak bisa dilepaskan dari perubahan kebudayaan. Dalam pandangan William Fielding Ogburn, penggagas Teori Guncangan Budaya (Cultural Lag), menyatakan bahwa perubahan-perubahan 
sosial meliputi unsur-unsur budaya, baik yang material maupun yang immaterial, yang ditekankan adalah pengaruh besar unsur-unsur kebudayaan materiil terhadap unsur-unsur immaterial (Lestari, 2008: 22). Terkait hal tersebut, Tradisi Majejahitan sebagai suatu identitas masyarakat Hindu Bali pada umumnya dan para wanita Hindu Bali pada khususnya kini semakin terpinggirkan seiring dengan meningkatnya tuntutan kebutuhan manusia yang semakin kompleks. Arus modernisasi, teknologi, dan informasi yang sedemikian pesat menuntut manusia untuk selalu meningkatkan aktivitas dan daya saing dalam menghadapi tantangan global, sehingga membawa kecenderungan pada diri manusia untuk mencari alternatif-alternatif untuk memudahkan hidupnya. Hal inilah yang dapat membawa implikasi yang besar bagi kebertahanan Tradisi Majejahitan sebagai warisan turun temurun masyarakat Hindu Bali, serta memunculkan tantangan bagi wanita Hindu Bali untuk menjaga eksistensi tradisi ini sebagai identitasnya di masa kini maupun di masa-masa mendatang.

\section{PEMBAHASAN}

\subsection{Konsep Tradisi Majejahitan}

Hakikat sebuah tradisi adalah suatu kegiatan yang telah menjadi sebuah kebiasaan dan berlangsung lama, serta dilaksanakan secara rutin, bahkan diwariskan secara turuntemurun. Kata tradisi yang dalam bahasa Inggris disebut tradition berasal dari bahasa Latin traditio. Istilah traditio sendiri berasal dari kata tradire yang artinya menyerahkan (Bagus, 2002:1115). Istilah tradisi dalam Ensiklopedi Nasional Indonesia adalah kebiasaan yang diwariskan dari satu generasi ke generasi berikutnya secara turun temurun. Kebiasaan yang diwariskan mencakup berbagai nilai budaya, yang meliputi adat-istiadat, sistem kemasyarakatan, sistem pengetahuan, bahasa, kesenian, sistem kepercayaan dan lain sebagainya (Tim Penyusun, 1997:414). Tradisi merupakan suatu unsur warisan sosio kultural 78 yang dilestarikan dalam masyarakat atau dalam kelompok-kelompok sosial masyarakat dalam kurun waktu yang panjang dari satu generasi ke generasi selanjutnya.

Bertolak dari konsep tradisi secara umum tersebut, maka Tradisi Majejahitan merupakan suatu warisan kultur yang telah berlangsung sejak lama dan mengalami beberapa kali proses pewarisan dari generasi ke generasi. Menurut Astawa (2009: 26), majejahitan merupakan suatu aktivitas keagamaan untuk mendapatkan bentuk-bentuk sarana upakara yang menjadi piranti upacara. Lebih jauh, Putera (2006: 1) menyatakan bahwa majejahitan adalah pekerjaan tangan dengan bahan utama daundaunan dan bambu. Hasilnya disebut jejahitan digunakan dalam upacara keagamaan sebagai alas persembahan, pelengkap busana pada bangunan suci dan peralatan upacara lainnya. Banyak diantaranya berbentuk sangat indah, dibuat dengan bahan yang segar dilengkapi bunga aneka warna sehingga berfungsi pula sebagai dekorasi.

Tradisi Majejahitan di Bali identik dengan kegiatan merangkai janur dalam rangka mempersiapkan kelengkapan bahan-bahan upacara yadnya. Tradisi Majejahitan merupakan suatu aktivitas yang telah menjadi kebiasaan turun-temurun yang lazim dilakukan oleh wanita Hindu Bali, terutama menjelang hari-hari raya dalam Agama Hindu. Dalam rangka menyongsong hari raya Hindu yang tentunya sangat memerlukan sarana-sarana upakara yadnya, para wanita Hindu di Bali berkumpul di suatu tempat (umumnya di bale banjar) dan mulai aktivitas majejahitan yang dilaksanakan bersama-sama.

Pelaksanaan Tradisi Majejahitan sarat dengan nilai-nilai pendidikan dan makna filosofis. Aktivitas pelaksanaannya akan menciptakan pola-pola interaksi sosial, baik antar-individu, antar-keluarga, dan bahkan antar-masyarakat. Terlebih hasil karya jejahitan tersebut akan dipergunakan untuk sarana upacara yadnya, sehingga dari proses pembuatannyapun para wanita Hindu Bali 
dituntut untuk berada dalam kondisi yang suci lahir batin. Kesucian lahir, dimana wanita yang mengikuti tradisi ini haruslah tidak dalam keadaan cuntaka (haid). Sedangkan kesucian batin dimana saat mengikuti tradisi ini haruslah senantiasa berpikir yang baik, berkata yang baik, serta berbuat atau berkelakuan yang baik. Apabila hal ini dilanggar, maka diyakini akan mencemari kesucian sarana-sarana yang dibuat, sehingga konsekuensinya adalah upacara yadnya yang akan dilaksanakan tidak akan mencapai hasil yang diharapkan. Terlebih dalam upacara yadnya, yang menjadi unsur pokok pelaksanaannya adalah rasa ketulusikhlasan, sehingga pikiran, perkataan, dan perbuatan yang tidak baik akan mencerminkan ketidaktulusikhlasan dalam memberi pelayanan kepada Ida Sang Hyang Widhi Wasa. Oleh sebab itu, pikiran, perkataan, dan perbuatan hendaknya diarahkan ke arah yang baik demi terciptanya keharmonisan, baik dalam kehidupan beragama maupun bermasyarakat.

\subsection{Tradisi Majejahitan dalam Dinamika Perubahan Sosial Budaya}

Perubahan sosial menurut Gillin dan Gillin (dalam Lestari, 2008: 22) bahwa perubahan-perubahan sosial untuk suatu variasi cara hidup yang lebih diterima yang disebabkan baik karena perubahan kondisi geografis, kebudayaan materiil, kempetisi penduduk, ideologi, maupun karena adanya difusi atau perubahan- perubahan baru dalam masyarakat. Perubahan sosial dalam masyarakat mempengaruhi system social, nilai-nilai, sikap, dan pola perilaku masyarakat (Selo Soemardjan dalam Marlina, tt: 8). Dalam perspektif Teori Ketertinggalan Budaya (Cultural Lag), Ogburn menyatakan bahwa beberapa ciri atau karakteristik perubahan sosial budaya adalah:

1) Perubahan selalu disertai guncangan, karena budaya materi diterima lebih cepat daripada budaya nonmateri.
2) Kesenjangan dalam kecepatan penerimaan menimbulkan ketimpangan budaya (cultural lag).

3) Kesenjangan juga terjadi karena antarbudaya nonmateri ada perbedaan kecepatan penerimaannya oleh masyarakat.

4) Guncangan terjadi juga akibat perbedaan individu dalam menerima komponen budaya baru.

5) Setiap masalah sosial dapat dijelaskan sebagai cultural lag (file.upi.edu, diakses 13 Oktober 2014).

Beranjak dari hal tersebut, dapat dinyatakan bahwa keberlangsungan Tradisi Majejahitan sebagai identitas wanita Hindu Bali dalam dinamika perubahan sosial dihadapkan pada tantangan yang serius. Dalam arus perkembangan teknologi yang demikian pesat, eksistensi tradisi ini mengalami berbagai kesenjangan sosial. Beberapa penyebab kesenjangan sosial tersebut dengan merujuk pada pandangan Micklin (dalam Sjafari dan Nugroho, 2011: 9) yang menyatakan bahwa perubahan-perubahan sosial disebabkan faktorfaktor sebagai berikut.

1) Teknologi sebagai penyebab perubahan sosial.

2) Gerakan massa. Di dalam suatu masyarakat ada sub-sub kelompok tertentu sebagai suatu pergerakan sosial, yang sangat kuat dan aktip bahwa mereka dapat memulai perubahan sosial atau mempercepat perubahan. Yang mungkin dapat digolongkan seperti seorang reaksioner, konservatif, penganut pembaharuan, dan revolusioner (Storer dalam Sjafari dan Nugroho, 2011: 9).

3) Adanya nilai-nilai dan gagasan baru. Perubahan sosial terjadi ketika ada gagasan yang baru dan nilai-nilai baru. Gagasan dan nilai-nilai baru memungkinkan mereka untuk hidup menjadi lebih selaras dengan lingkungan yang berubah. 
4) Perubahan pada transportasi dan komunikasi. Telah ada suatu tambahan kecepatan (akselerasi) dari perubahan transportasi dan komunikasi dari masa lalu sampai dengan saat ini. oleh karena perubahan ini, orang bisa menaklukkan ruang dan waktu.

Perubahan sosial budaya yang terjadi dalam suatu komunitas masyarakat akan membawa perubahan dalam tatanan sosial masyarakat sebagai konsekuensinya. Menurut pandangan Auguste Comte sebagai salah satu tokoh Teori Perubahan Sosial, beberapa ciri tatanan sosial baru (modernitas) adalah:

1) Konsentrasi tenaga kerja di pusat urban.

2) Pengorganisasian pekerjaan yang ditentukan berdasarkan efektivitas dan keuntungan.

3) Penerapan ilmu pengetahuan dan teknologi dalam proses produksi.

4) Munculnya antagonisme terpendam atau nyata antara majikan dan buruh.

5) Berkembangnya ketimpangan dan ketidakadilan sosial.

6) Sistem ekonomi berlandaskan usaha bebas dan kompetisi terbuka (Stzompka, 2007: 82).

Dengan perubahan pola hidup di zaman yang menuntut segala sesuatunya serba cepat, masyarakat dituntut untuk mampu menyesuaikan diri, termasuk dalam aspek kehidupan religius. Ogburn memandang bahwa ketegangan budaya disebabkan oleh derasnya budaya materiil yang datang pada sebuah masyarakat. budaya materiil tersebut kemudian diadopsi dan digunakan untuk memenuhi kebutuhan masyarakat (Supriatna, 2002: 37). Di satu sisi para wanita Hindu Bali semakin dimudahkan dalam memperoleh segala kebutuhannya, karena hanya tinggal membeli yang sudah jadi, termasuk pula bahan-bahan upacara yang hanya tinggal mempergunakan saja tanpa bersusah payah membuatnya dengan alasan sibuk berkarier, tidak sempat, atau tidak ada waktu untuk itu. Disamping itu pula, hal ini tentu saja menguntungkan para pelaku ekonomi Hindu Bali. Namun di sisi lain, perubahan yang terjadi dalam tatanan sosial budaya masyarakat Bali turut membawa implikasi bagi keberlangsungan Tradisi Majejahitan sebagai salah satu identitas wanita Hindu Bali. Beberapa implikasinya adalah:

1. Memudarnya interaksi sosial antar-wanita Hindu Bali sebagai warga masyarakat Bali. Dalam Tradisi Majejahitan yang sebagian besar dilaksanakan para wanita Hindu Bali, tidak saja terjadi aktivitas pembuatan sarana-sarana upacara, namun juga terjadi proses interaksi sosial. Aktivitas Tradisi Majejahitan yang mengarahkan para wanita untuk berkumpul, dan berbaur, serta berinteraksi akan menciptakan rasa persatuan dan kesatuan yang kuat serta menumbuhkan kecintaan sebagai warga masyarakat. Namun dengan perubahan tatanan sosial budaya masyarakat Bali dewasa ini, hal tersebut akan semakin meluntur.

2. Hilangnya pemaknaan nilai-nilai luhur dalam tradisi. Dengan memudarnya aktivitas pelaksanaan Tradisi Majejahitan yang sakral, para wanita Hindu Bali di zaman global seperti sekarang sering sudah tidak mengetahui lagi nilai-nilai luhur serta makna filosofis yang terkandung di dalamnya. Dengan perubahan pola hidup, para wanita Hindu Bali cenderung mencari alternatif-alternatif yang cepat dan praktis untuk memenuhi kebutuhan akan bahanbahan upacaranya.

3. Perubahan nilai Tradisi Majejahitan yang sakral menjadi Tradisi Majejahitan yang profan. Keberlangsungan Tradisi Majejahitan yang semakin memudar tidak saja dari segi kuantitasnya, namun juga dari aspek kualitas religiusitasnya. Sudiarja (2010: 35) menyatakan bahwa perkembangan ilmu pengetahuan yang 
dibawa oleh arus globalisasi menawarkan cara penjelasan yang lebih rasional untuk kenyataan kehidupan karena didukung oleh perangkat yang canggih daripada teologi tradisional yang sering mengalami kendala dalam menjelaskan apa yang disebut sebagai fakta. Akibatnya agama juga mengalami ambivalensi dalam menghadapi tawaran globalisasi.

Para wanita Hindu Bali yang memang menggantungkan hidupnya dari sektor ekonomi, menjual bahan-bahan upakara akan diuntungkan, namun dapat dipastikan aspek religiusitasnya akan cenderung diabaikan. Hal ini karena orientasi pelaksanaannya hanyalah untuk mencapai keuntungan finansial.

Krisis identitas di kalangan wanita Hindu Bali. Perkembangan teknologi dan informasi yang demikian pesat menuntut masyarakat untuk selalu berdinamika mengikuti perubahan zaman. Ardika (dalam Titib, 2007:42) menyatakan bahwa proses globalisasi telah pula merambah kehidupan agama yang sakral menjadi sekuler, yang dapat menimbulkan ketegangan bagi umat beragama. Nilai-nilai yang mapan selama ini telah mengalami perubahan yang pada gilirannya menimbulkan keresahan psikologis dan krisis identitas di kalangan masyarakat. Para wanita Hindu Hindu Bali dapat diidentifikasi dengan keahliannya majejahitan sekarang sudah tidak banyak lagi yang bisa melakukannya. Pandangan Ogburn menyatakan bahwa:

Kebudayaan nonmateriil seperti kebiasaan dan tatacara organisasi sosial yang akhirnya berkonsekuensi harus menyesuaikan diri dengan kebudayaan-kebudayaan maateriil. Kebudayaan nonmateriil yang tidak mampu mengejar karena kecepatan perubahan dalam dalam kebudayaan maeriil terus melaju. Hasilnya adalah ketegangan yang terus meningkat antara budaya materiil dengan non materiil, akhirnya selalu menimbulkan ketinggalan budaya (cultural lag) khususnya budaya nonmateriil (Hodijah, 2013: 5-6).

Tradisi Majejahitan yang dulunya merupakan suatu hal yang lazim dilaksanakan para wanita Hindu Bali, dan bahkan disematkan sebagai sebuah identitas bagi mereka kini semakin terpinggirkan. Hal ini terjadi seiring perubahan orientasi masyarakat yang cenderung mementingkan aspek material dan finansial daripada memahami nilai-nilai dan makna filosofi dalam tradisi-tradisi keagamaan, sehingga krisis identitas suatu kensekuensi yang tidak dapat dihindari.

\section{KESIMPULAN}

Tradisi Majejahitan merupakan salah satu aktivitas yang memadukan unsur religiusitas (kesucian lahir batin), keterampilan, dan interaksi antar-wanita Hindu Bali. Tradisi ini telah menjadi sebuah identitas yang disematkan pada para wanita Hindu Bali. Dalam perkembangan arus globalisasi dan modernisasi yang demikian deras, eksistensi tradisi ini mengalami suatu guncangan akibat dinamika sosial budaya yang mengalami perubahan. Hal ini berdampak pada berkurangnya kualitas dan kuantitas pelaksanaan kegiatan tradisi ini. Implikasi yang lebih serius adalah timbulnya krisis identitas wanita Hindu Bali seiring dengan perubahan zaman. Oleh sebab itu perlu ada langkah-langkah serius dari pihak-pihak terkait (masyarakat Hindu Bali, para akademisi, dan pemerintah) untuk mempertahankan eksistensi Tradisi Majejahitan sebagai penyelamatan identitas wanita Hindu Bali dalam gempuran globalisasi. 


\section{DAFTAR PUSTAKA}

Astawa, I Nyoman. 2009. "Tradisi Majejahitan Sebagai Media Kerukunan Hidup Intern Umat Beragama dalam Masyarakat Hindu Multietnis di DKI Jakarta". Tesis Program Pascasarjana IHDN Denpasar.

Bagus, Lorens. 2002. Kamus Filsafat. Jakarta: Gramedia Pustaka Utama.

file.upi.edu (diakses 13 Oktober 2014)

Hodijah, Ijah. 2013. Nilai-nilai Tradisi Ruwatan Bumi Sebagai Sumber Pembelajaran Sejarah Untuk Meningkatkan Tanggung Jawab Siswa (Mixed Method Dengan Studi Etnografi Pada Masyarakat Adat Banceuy dan PTK di SMP Negeri 1 Ciater Kabupaten Subang). Universitas Pendidikan Indonesia (repository.upi.edu diakses tanggal 15 Oktober 2014).

Lestari, Puji. 2008. Analisis Perubahan Sosial pada Masyarakat Samin (Studi Kasus Di Desa Mendenrejo, Kecamatan Kradenan, Blora), termuat dalam Jurnal Dimensia, Volume 2, No. 2, September 2008, Uiversitas Negeri Yogyakarta (staff.uny.ac.id, diakses tanggal 13 Oktober 2014).

Marlina, Murni Eva. tt. Perubahan Sosial Budaya Masyarakat Tembung Dengan Pemakaian Keyboard Pada Pesta Pernikahan (akademik.nonmensen.id.org/ diakses pada13 Oktober 2014).

Putera, I Gst. Ag. Mas. 2006. Majejahitan (Merangkai Janur di Bali). Denpasar: Pemerintah Provinsi Bali.

Sjafari, Agus dan Kandung Sapto Nugroho. 2011. Perubahan Sosial Sebuah Bunga Rampai. Banten: FISIP Untirta (lab.ane.fisip.untirta.ac.id, diakses tanggal 13 Oktober 2014).

Sudiarja, A. 2010. Agama (di Zaman) yang Berubah. Yogyakarta: Kanisius.
Supriatna, Encep. 2012. Transformasi Pembelajaran Sejarah Berbasis Religi dan Budaya untuk Menumbuhkan Karakter Siswa, termuat dalam Jurnal Atikan, Volume 2, No. 1, 2002 Fakultas Pendidikan Ilmu Pengetahuan Sosial Universitas Pendidikan Indonesia (atikanjurnal.com, diakses tanggal 14 Oktober 2014).

Sztompka, Piotr. 2007. Sosiologi Perubahan Sosial. Jakarta: Prenada.

Tim Penyusun. 1997. Ensiklopedi Nasional Indonesia. Jakarta: Delta Pamungkas.

Titib, I Made. 2007. Teologi Hindu (Brahmavidya) Study Teks dan Konteks Implementasi. Denpasar: Program Pascasarjana IHDN. 